\title{
HEALTH EDUCATION AND ITS THEORETICAL PERSPECTIVES: A FEW REFLECTIONS
}

\author{
Maria Aparecida Salci ${ }^{1}$, Priscila Maceno², Soraia Geraldo Rozza3a, Denise Maria Guerreiro Vieira da Silva , \\ Astrid Eggert Boehs ${ }^{5}$, Ivonete Teresinha Schulter Buss Heidemann ${ }^{6}$
}

\footnotetext{
${ }^{1}$ Student of the Doctoral Program in Nursing at Federal University of Santa Catarina (UFSC). Professor of the Department of Nursing at The State University of Maringá. CNPq fellow. E-mail: masalci@uem.br

2 Student of the Master's Program in Nursing at UFSC. Capes fellow. E-mail: priscilamaceno@gmail.com

${ }^{3}$ Student of the Master's Program in Nursing at UFSC. Capes fellow. E-mail: so_rozza@hotmail.com

${ }^{4}$ Ph.D. in Nursing Philosophy. Professor of the Undergraduate and Graduate courses at UFSC. Santa Catarina, Brasil. E-mail: denise@ccs.ufsc.br

${ }^{5}$ Ph.D. in Nursing Philosophy. Professor of the Undergraduate and Graduate courses at UFSC. Santa Catarina, Brasil. E-mail: astridboehs@hotmail.com

${ }^{6}$ Ph.D. in Public Health. Professor of the Undergraduate and Graduate courses at UFSC. Santa Catarina, Brasil. E-mail: heideman@uol.com.br
}

\begin{abstract}
The purpose of this study was to reflect theoretically on the theme of health education and how it interfaces with health promotion. It consists of a theoretical-reflexive study aimed at comparing these practices to the concepts elaborated in the Letter of Ottawa, the pedagogy of liberation of Paulo Freire, empowerment and culture, here comprehended as key elements guiding the activity of the nurse in health education in actions performed by health services. In order to take this reflexive path, the authors analyzed the interrelationships of these theoretical interfaces and their approaches to health promotion practices. From this presented theoretical framework, it is possible to reflect on the possibilities of extending care, based on the premise that all moments comprising interaction with patients of health services must be considered an opportunity to develop health education actions, considering the knowledge of nurses characterized as social actors who are responsible for the events that take place in the health scenario.
\end{abstract}

DESCRIPTORS: Health education. Health promotion. Nursing.

\section{EDUCAÇÃO EM SAÚDE E SUAS PERSPECTIVAS TEÓRICAS: ALGUMAS REFLEXÕES}

RESUMO: O objetivo do artigo foi refletir teoricamente acerca da temática educação em saúde e suas interfaces na promoção da saúde. Trata-se de um estudo teórico-reflexivo, que procurou cotejar essas práticas com as concepções da carta de Ottawa, a pedagogia libertadora de Paulo Freire, o empoderamento e a cultura, aqui compreendidos como elementos-chave para a atuação do enfermeiro na educação em saúde em ações nos serviços de saúde. Para esse percurso reflexivo, realizamos as inter-relações dessas vertentes teóricas e suas aproximações com as práticas de promoção da saúde. A partir do arcabouço teórico apresentado, podemos refletir sobre possibilidades de ampliação do cuidar, embasadas na premissa de que todos os momentos que compreendem interação com os usuários dos serviços de saúde devem ser considerados propícios para desenvolver ações de educação em saúde, haja vista o conhecimento dos enfermeiros, caracterizados como atores sociais responsáveis pelos acontecimentos no cenário da saúde.

DESCRITORES: Educação em saúde. Promoção da saúde. Enfermagem.

\section{LA EDUCACIÓN PARA LA SALUD Y SUS PERSPECTIVAS TEÓRICAS: ALGUNAS REFLEXIONES}

RESUMEN: El objetivo de este trabajo fue reflexionar teóricamente sobre el tema de la educación para la salud y sus interfaces en la promoción de la salud. Se trata de un estudio teórico-reflexivo, que busca comparar estas prácticas con las opiniones de la Carta de Ottawa, la pedagogía liberadora de Paulo Freire, el empoderamiento y la cultura, entendidas aquí como elementos clave para el desempeño de los profesionales de la salud en la educación sanitaria en acciones en los servicios de salud. Para esta línea de pensamiento, realizamos las interrelaciones de estos componentes teóricos y sus prácticas con las prácticas de promoción de la salud Desde el marco teórico presentado, podemos reflexionar sobre las opciones para ampliar la atención, basada en la premisa de que todos los momentos que incluyen la interacción con los usuarios de los servicios de salud deban ser considerados propicios para la conducción de la educación en salud, teniendo en cuenta el conocimiento de los enfermeros, que son los actores sociales responsables de los hechos en el escenario de la salud.

DESCRITORES: Educación en salud. Promoción de la salud. Enfermería. 


\section{INTRODUCTION}

Health education is a complex theme due to the several dimensions that comprise it, including political, philosophical, social, religious and cultural dimensions, in addition to involving practical and theoretical aspects of the individual, group, community and society. Moreover, it involves the health-disease process in the two aspects of this action in health, necessary for health maintenance or to avoid and/or delay the presence of disease, and essential to provide quality of life to people and/ or delay the complications of the disease process.

The concept of health education is linked to the concepts of both education and health. Traditionally, it is understood as the transmission of information in health, with or without the use of more advanced technologies, whose reviews have evidenced its ability to handle the complexity involved in the educational process. Critical and participative concepts have achieved spaces and comprehend health education as actions developed to achieve health, being considered "a set of pedagogical practices of participative and emancipatory character, which spans several action fields and aims at mobilizing and making people sensitive and aware to face individual and collective situations that interfere in the quality of life" ${ }^{\prime 1: 17}$

In this sense, health education cannot be reduced only to practical activities that involve the transmission of information in health. It is considered an important tool in health promotion, which requires a combination of educational and environmental support aimed at achieving actions and conditions of life conducive to health. ${ }^{2}$

The association of this practice with communication, information, education ${ }^{3}$ and qualified listening ${ }^{4}$ is vital so that health promotion effectively takes place, with the instrumentalization of health education, in addition to the comprehension of this theme, and the concepts and aspects it comprises.

Communication spans all practices and actions, including mainly elements of education, persuasion, mobilization of public opinion and social participation. Information is based on helping in the choice of behaviors, the prevention of diseases, the development of a health culture and the democratization of information. Education is present in personal contact, so that any environment may be considered opportune for this purpose; it is also present in the impersonality of mass communication with the aid of several channels of media and technologies such as the television, the radio and the Internet. ${ }^{3}$ Qualified listening is a fundamental skill for all health professionals and means to develop the ability to listen carefully to the narratives of people, remembering that the process of narrating a fact may allow people to modify their way of facing and acting towards a certain situation. ${ }^{4}$

The purpose of this study was to reflect theoretically on the theme of health education and its interfaces in health promotion. It was oriented by the following guiding question: which aspects span the field of health education and its theoretical interfaces in health promotion for the professional practice?

This theoretical-reflexive study aims at comparing these practices to the concepts outlined in the Letter of Ottawa, the Paulo Freire's pedagogy of liberation, empowerment and culture, understood here as key elements for the activity of the nurse working in health education in actions of health services. For this reflexive path, the authors combined interrelationships of these theoretical aspects and their approaches to the practices of health promotion.

The texts that subsidized this reflection included documents that are considered as references in the area of health promotion and education, such as the Letter of Ottawa ${ }^{5}$ and texts regarding the critical pedagogy of Paulo Freire, as well as authors who have interpreted these works in the health area. ${ }^{6-7}$ The concept of empowerment was discussed from the autonomy perspective. ${ }^{8-9}$ Questions regarding culture were subsidized by the interpretivist perspective, through authors who discuss it in the health area. ${ }^{4-10}$ The selected material approaches the relationship of health education and health promotion, which are essential for the comprehension of the context, relations and correlations of the presented proposals.

\section{Letter of Ottawa and health education}

Health promotion is a broad concept aimed at global well-being. This concept is associated with a set of values: life, health, solidarity, equity, democracy, citizenship, development, participation and fields of joint action. It also refers to a combination of actions stemming from healthy public policies, the creation of a healthy environment, reinforcement of community action, development of personal skills and reorientation of the health system. ${ }^{5}$ 
One of the essential requisites for health is education ${ }^{5}$; thus, health promotion supports personal and social development through the transmission of information, health education and intensification of vital skills.

Hence, among the five fields of actions proposed by the Letter of Ottawa ${ }^{5}$, the development of personal skills stands out, since it is possible to view the autonomy of the individual in them, stimulating his/her capabilities using a variety of health education strategies, emphasizing educational programs aimed at high-risk behaviors and habits that are susceptible to change.

These tasks may be performed in schools, homes, work places and other community spaces. The actions must be performed through educational, professional, commercial and voluntary organizations, as well as through governmental institutions. ${ }^{5}$

The reinforcement of personal development actions with an emphasis on health education highlights the Salutogenic Theory proposed by Aaron Antonovsky, which aimed at comprehending the potential for people not to become ill from the narrative of holocaust survivors, using interviews with women who had survived the Nazi extermination camps. ${ }^{11}$ Based on these narratives, the Salutogenic Theory and its concepts were elaborated, yielding the questionnaire - The Salutogenic Concept Sense of Coherence (SOC) - with orientation to life. SOC is a resource/instrument that orients the health promotion of an individual, group or society. Thus, Salutogenesis is a process that enables people to live life as they want to, promoting the ability to overcome and recover from adversities, establishing positive health promotion as the main focus. ${ }^{11}$ This perspective is related to the Letter of Ottawa, highlighting that health must be used as a resource for life, instead of as a purpose to live..$^{5}$ In this sense, health is a positive concept, contrary to the biomedical model in which the main focus is the prevention of negative health, and being healthy is understood as the absence of disease..$^{5-12}$

Therefore, it is perceived that Salutogenesis agrees with the actions proposed in the Letter of Ottawa, since it reinforces that health promotion is the process of enabling individuals and communities in the development of personal skills. The Salutogenic Theory and the concept of health promotion supported the construction process of health promotion present in the National Policy of Health Promotion (NPHP).
The NPHP states that by resuming the action strategies proposed by the Letter of Ottawa and analyzing the literature in the area, it can be observed that, until now, the development of studies happened most often in connection with initiatives associated with the behaviors and habits of individuals. ${ }^{13}$

Hence, it is perceived that the guidelines proposed for the formulation of the NPHP are intimately related to the individual's lifestyle, which may directly influence his/her health. In the NPHP, health education structures and strengthens health practices that are sensitive to the reality of the country.

The actions of the Letter of Ottawa apply to the NPHP as playing one of the fundamental roles in health promotion. Therefore, the actions of health promotion/education must seek support in the specific actions of the municipal administration of the $\mathrm{NPHP}$, such as: healthy nutrition, exercise/physical activity and tobacco prevention and control. As an example, it is possible to highlight the treatment and support provided to smokers, in which one of the specific actions in the NPHP is to increase the smoker's access to efficient methods to quit smoking, thus meeting a growing demand from smokers who are seeking support for this purpose. ${ }^{13}$

The NPHP, within its specific actions, focuses on the importance of the campaign against tobacco use, which according to salutogenesis should be first initiated with healthy individuals, supplying physical and psychological needs, and then moving outwards in a more generalized way to increase individual resistance.

Vulnerability is one area where the possibility of mobilizing resources takes place, considering that the concept of salutogenesis stimulates potential. This is different from the campaigns against tobacco that occurred recently in Brazil, which emphasized unhealthy people with diseases caused by tobacco in order to "intimidate" the individual to reduce consumption by labeling cigarette boxes with photographs of sick people.

It is perceived that, in Brazil, there is still a long path to be taken and enormous challenges presented in the quest for health promotion. ${ }^{13}$ It becomes necessary, through actions of health education, to recover the autonomy of the individual and to promote the emancipation of the community, for an effective approach and operationalization of the concept of positive health promotion proposed by the Letter of Ottawa and the Salutogenic Theory. 


\section{Paulo Freire's Pedagogy of Liberation and} health education

Freire's Pedagogy of Liberation, which proposes the emancipation and autonomy of the individual, initially proposed the literacy of young people and adults and, gradually, was being used as an important methodology to improve health promotion. This liberating and problem-solving pedagogical proposal goes beyond the limits of education and is also understood as a way of reading the world, reflecting on this reading and retelling it, transforming it by conscious action. ${ }^{7}$

The concept of education as a process involving action-reflection-action enables people to learn, evidencing the need for a concrete cultural, political and social action aimed at "limiting situations" and overcoming contradictions. ${ }^{14}$ Thus, the relationship between health education and the pedagogy of liberation, which is based on a horizontal dialogue between professionals and patients, contributes to the construction of the individual's emancipation towards the development of individual and collective health.

As a strategy for the development of health education, it is possible to use the Circle of Culture proposed by Paulo Freire. Circle of Culture is a term created to represent a dynamic space of learning and knowledge exchange. Individuals gather in the education process to investigate themes of interest common to the group. It represents a situation-problem of real circumstances, which leads to the reflection of reality so that, afterwards, it is possible to decode and recognize it. ${ }^{14}$ It is a powerful strategy of horizontal communication, since the sharing of experiences, in a common language that is accessible to all the group members, will certainly contribute to the choice of the most efficient and effective intervention. ${ }^{3}$

The traditional model of health education is criticized by Freire, who terms it bank education, ${ }^{6}$ considered as an act of depositing and transferring values and knowledge. ${ }^{14}$ Vertical dialogue is experienced in this model and the student is a passive being, which is the opposite of the pedagogy proposal of Paulo Freire, as it assumes a dialogical model that is essential for health education.

Nevertheless, the use of the dialogical approach requires professionals to change their attitude, breaking with authoritarian behavioral standards, recognizing that the educator also needs to be open to the other so that new knowl- edge is constructed; that is, "the educator is not only the person who educates, but a person who while educates, is also educated". ${ }^{14: 39}$ In this education process, hierarchy is broken between the one who knows and the one who does not know, but there is the acknowledgement that both know different things.

Although health education is one of the instruments of health promotion, this practice has been poorly disseminated within the health care system, highlighting the need for professionals in this area to receive further education composed of new methodological possibilities of activity.

\section{Empowerment and health education}

The concept of empowerment is indirectly related to the definition of autonomy, thus emphasizing the capability of individuals and groups to decide on questions of concern to them, such as: politics, economy, health and culture, among other aspects of social and individual order.

A classic concept defines empowerment as "a construct that connects individual competencies and strengths, natural help systems and proactive behaviors with social policies and changes" ${ }^{8: 1}$ It consists of the constitution of responsible communities and organizations through a process in which the individuals composing it obtain control over their lives and participate democratically in daily collective arrangements, with competence to criticize their environment.

Nevertheless, empowerment should not mean a purely instrumental concept, oriented only towards achieving efficient results, but as an instrument that is capable of constituting a statement of the possibilities of full accomplishment regarding people's rights. Empowerment may be used as a way to foster health promotion, developing health education with individual and collective actions that bring effective results, and evidencing this referential as a tool that may be used for health promotion. Two types of empowerment stand out: psychological and social/community. The psychological type recovers individual potentials so that the person has greater control over his/her own life. Social empowerment, on the other hand, is a process that leads to legitimization and gives voice to marginalized groups, at the same time removing barriers that limit the production of a healthy life for different social groups. ${ }^{9}$

In order to promote both individual and collective empowerment, it is fundamental to de- 
velop a method that spans the substrates of health education, detached from an imposing educational practice, with subtle seduction games so that the individual may acquire the necessary tool for his/ her empowerment. ${ }^{9}$

Therefore, in order to empower a person, the dialogical model becomes appropriate so that health education is the key instrument of this proposal, which aims to convert the passivity of individuals into an active and critical position in face of the completeness of scientific knowledge. ${ }^{15}$ This model favors the collective and individual construction of knowledge, allowing a critical and reflexive view of reality in which the health professional, especially the nurse, has an important role in co-responsibility and qualification for the construction of empowerment, mainly that related to health.

In nursing care, it is possible to start this process from the presupposition that the construction of knowledge is made up of a partnership between nurses and individuals, which may advance beyond the biological paradigm focused on the disease, in order to construct a new paradigm focused on the search for a healthy human being, promoting both collective and individual health. This is justified by the articulated mobilization in the real health scenario of a community, which constitutes an arena with the possibility to deconstruct and transform the individual's reality. ${ }^{16}$ Hence, through empowerment, health promotion aims to allow both individuals and the collective to learn and become capable of living life in its different stages, dealing with the limitations imposed by occasional illnesses. ${ }^{9}$

It is worth highlighting that individual empowerment occurs internally at first, in which the individual takes possession of information related to his/her current condition. Later, the individual becomes capable of possessing the necessary knowledge to promote personal changes and influence changes in the group, using this acquired empowerment as a personal skill. ${ }^{9}$ Empowerment stands out, thus, as a personal skill that contributes to the response to the challenges of life in society and to aspects related to the health-disease process.

Individual empowerment brings a greater interaction of the individuals with their health and a greater consciousness in making decisions related to needed care, informing the way they wish to be treated and providing the autonomy to make the choices they judge most important in their lives, without knowledge and awareness of the advantages and disadvantages that permeate these choices.

\section{Health education and culture}

A classic concept of culture is presented as a set of features that characterize all human beings, and which singularize each and every one of them as a different person with particular interests, capabilities and emotions. ${ }^{17}$

Culture may still be defined as a set of elements that mediate and qualify any physical or mental activity that is shared by different members of a social group, but not determined by biology. It consists of elements upon which social actors construct meanings for concrete and temporal social interactions and actions, as well as support the current social forms, institutions and their operative models. Culture includes values, symbols, rules and practices. ${ }^{10}$

The acknowledgement of culture as part of nursing care is fundamental in health care and includes the understanding that the knowledge of professionals and people who seek care integrate different health subsystems. This concept is based on the understanding of health as a cultural system, comprised of professional, family and popular subsystems. ${ }^{4-10}$

In a study developed regarding the main concepts present in the work of Paulo Freire, the concept of culture represents the sum of all experiences, creations and recreations associated with men in their current space and in their past experience, configuring it as the real manifestation of men over the world. Culture, thus, is a quicksand of meanings undergoing eternal change, which is presented as the new come-to-be. ${ }^{18}$

In the current health care model, the aspects that outline people's culture must be highlighted. Thus, the professional must acknowledge the culture of the subjects, aimed at apprehending their way of seeing the world in order to recognize their social and family context, which provides clues to developing health education focused on the reality and encompassing the world lived in by the subject.

The Family Health Strategy, which proposes to develop health care in the context in which people live, constitutes the perfect scenario for these ideas to be carried out in practice. Being a care model that acts in the coverage area of the target population, it requires from nurses a knowledge of this population and the specifics of the local cul- 
ture, and thus aims to provide health care aimed at the reality of the community, considering its needs and potentials for health education, which may achieve the principles of health promotion. ${ }^{4}$

It is important to highlight that the practice of many nurses is still focused on the disease and that health education, as an instrument for health promotion, has been performed through traditional educational approaches, in which culture is taken as reference. In this sense, it is vital to develop an educational process based on the acknowledgement of this cultural reality, enabling them to build a new acknowledgment. This requires a pedagogical concept in which dialogue and respect for the other is the activity referential of health professionals.

\section{A FEW REFLECTIONS}

Health education is an important tool for health promotion, involving theoretical and philosophical aspects which must orient the practice of all health professionals. In order to develop work convergent with the principles of health promotion, as proposed in the Letter of Ottawa, there is the need to emphasize the development of personal and social skills through health education, developed in a dialogical and liberating way.

In face of the theoretical relationships among health education, health promotion, empowerment and culture, and the understanding of the role of nurses and their actions in health education aimed at health promotion, it is necessary to elucidate the theoretical comprehension that involves these themes. Thus, it becomes necessary to have a critical-reflexive and committed attitude, aimed at the other. All moments involving interaction with patients of health services must be considered favorable for the development of actions in health education. For instance, it is possible to highlight: appointments, technical procedures, nursing care interventions, collective actions such as group meetings, and less formal gatherings in which there is the possibility of establishing dialogue. It is also necessary to recover the principles of communication, information, education and qualified listening so that these educational actions are effective and relevant.

These actions correspond to the practical applicability of the proposals of action fields detailed in the Letter of Ottawa, which comprised the creation of healthy environments, development of personal skills, proposition of healthy public policies, reinforcement of community action and reorientation of the health system.

In the construction of an emancipatory context, there is the need for nurses to visualize new ways of intervening in the healthy reality, basing their professional practice on the respect and trust in the potential of human beings with whom they interact and form partnerships in actions of health education. The emancipatory power involves the instrumental and communicative knowledge. In order to make this movement happen, all principles of integrality must be followed and people must be empowered in the process of taking care of oneself.

It is also important to highlight that culture must be considered by nurses in the aspects that comprehend health care and education, since this theme directly reflects the way people live and relate in society.

In light of the complexity of the theme Health Education, but with the comprehension of the magnitude that comprises all questions involving it- the professional must develop emancipatory actions of health promotion that go beyond the biomedical model, acting in a participative way so that people obtain the necessary knowledge to make conscious decisions regarding their healthy living and health-disease process.

This fact comprehends a "new perspective of health promotion", which aims at reaching a "new health-disease process" so that healthy people may take better care of their health, inserting healthier practices into their daily routine. This reflection aims at the divide between the biomedical paradigm and the care of healthy people in the living process.

Therefore, in light of the theoretical framework presented, it is possible to reflect on possibilities for broadening the ways of providing care and acting, based on the premise that all health actions must be considered favorable under these conditions, given the availability of nurses characterized as social actors who are responsible for events in this scenario; that is, in the health context.

\section{REFERENCES}

1. Ministério da Saúde (BR). Temático promoção da saúde IV. Brasília (DF): Organização Pan-Americana da Saúde; 2009.

2. Candeias NMF. Conceitos de educação e de promoção em saúde: mudanças individuais e mudanças organizacionais. Rev Saúde Pública. 1997 Abr; 31(2):209-13. 
3. Buss PM. Promoção e educação em saúde no âmbito da escola de governo em saúde da Escola Nacional de Saúde Pública. Cad Saúde Pública. 1999; 15(Supl.2):177-185.

4. Bohes AE, Monticelli M, Wosny AM, Heidemann ITSB, Grisotti M. A interface necessária entre enfermagem, educação e saúde e o conceito de cultura. Texto Contexto Enferm. 2007 Abr-Jun; 16(2):307-14.

5. World Health Organization. The Ottawa charter for health promotion. Ottawa Canadá: WHO; 1986.

6. Figueiredo MFS, Rodrigues JFN, Leite MTS. Modelos aplicados às atividades de educação em saúde. Rev Bras Enferm. 2009 Jan-Fev; 63(1):117-21.

7. Heidemann ITSB. Possibilidades e limites para implantação da política de promoção da saúde na atenção básica: investigação de questões problemas. Edital MCT/CNPq n014/2010, Universal, Faixa A. Florianópolis (SC): Universidade Federal de Santa Catarina; 2010.

8. Perkins DD, Zimmerman MA. Empowerment meets narrative: listening tostories and creating settings. Am J Community Psychol. 1995 Oct; 23(5):569-79.

9. Carvalho SR, Gastaldo D. Promoção à saúde e empoderamento: uma reflexão a partir das perspectivas crítico-social e pós-estruturalista. Ciênc Saúde Coletiva. 2008; 13(Sup 2):2029-40.

10. Langdon EJ, Wiik FB. Antropologia, saúde e doença: uma introdução ao conceito de cultura aplicado às ciências da saúde. Rev Latino-am Enferm. 2010 MaiJun; 18(3):459-66.
11. Eriksson M, Lindström B. A salutogenic interpretation of the Ottawa Charter. Health Promot Int. 2008 Jun; 23(2):190-9. Epub 2008 Mar 20.

12. Lefevre F, Lefevre AMC. Saúde como negação da negação: uma perspectiva dialética. Physis Rev Saúde Coletiva. 2007 Jan-Abr;17(1):15-28.

13. Ministério da Saúde (BR). Anexo 1: Política Nacional de Promoção da Saúde [online]. 2006. [acesso 2010 Set 06]. Disponível em: http:/ / portal.saude.gov.br/ portal/arquivos/pdf/PNPS2.pdf

14. Freire P. Pedagogia do oprimido. $17^{\mathrm{a}}$ ed. Rio de Janeiro (RJ): Paz e Terra; 1987.

15. Alvim NAT, Ferreira MA. Perspectiva problematizadora da educação popular em saúde e a enfermagem. Texto Contexto Enferm. 2007 AbrJun; 16(2):315-9.

16. Santos MCM, Almeida SMO, Abrão FMS, Monteiro EMLM. Educação popular em saúde: um exercício de cidadania e valorização da cultura nordestina. ABEN/Anais eventos/SENABS [online]. 2009 [acesso 2011 Jun 16]. Disponível em: http:/ / www. abeneventos.com.br/SENABS/cd_anais/pdf/ id151r0.pdf

17. Matta RD. Você tem cultura? Jornal Embratel [online]. 2009 [acesso 2011 Mai 11]; Disponível em: http://naui.ufsc.br/files/2010/09/DAMATTA_ voce_tem_cultura.pdf

18. Vasconcelos MLMC, Brito RHPB. Conceitos de educação em Paulo Freire. São Paulo (SP): Vozes; 2006. 